sciendo Порівняльна професійна педагогіка 9(2)/2019 Comparative Professional Pedagogy 9(2)/2019

DOI: $10.2478 /$ rpp-2019-0020

Postgraduate Student, IRYNA KVASNYTSYA

Khmelnytskyi National University

Address: 11 Instytutska St., Khmelnytskyi, 29016, Ukraine

E-mail: irishakvas@gmail.com

\title{
ANALYSIS OF EXPERIENCE IN PROFESSIONAL TRAINING OF FUTURE SPECIALISTS IN PHYSICAL CULTURE AND SPORT IN HIGHER EDUCTIONAL ESTABLISHMENTS OF NORWAY AND SWEDEN
}

\begin{abstract}
The article analyzes experience of professional training of future specialists in physical culture and sports in higher educational establishments of Norway and Sweden. Research papers dealing with practice of realization of professional training of specialists in physical culture and sports abroad have been analyzed. Topicality of the research of professional training of future sports coaches in Scandinavian higher educational establishments has been proven. The fact that Scandinavian countries actively promote sports, advantages of physical culture, healthy lifestyle, health improving motor activity, and quality training of staff have been taken into account. The aim of the article is to define basics of the system of professional training of future specialists in physical culture and sport, namely sports coaches, in leading higher educational establishments of Norway and Sweden. The objectives of the research lie in the analysis of present-day state of physicalculture and sports education in Norway and Sweden; qualification trends and organizational peculiarities of professional training of specialists in the sphere of physical culture and sports in higher educational establishments of the aforementioned countries. Curricula of training program bachelors and masters of sports profile in Norway and Sweden have been characterized in the article. Peculiarities of educational programs of professional training of sports coaches in leading physical education and sport higher educational establishments of these countries have been defined. Curricula programs of Norwegian University for Sport and Swedish School of Sport and Health Sciences have been presented. It has been revealed that the systems of higher sport education in Norway and Sweden are characterized with educational trajectory of specialists training being expressed in succession of stages of education that a student has to complete in order to acquire knowledge, skills, competences, and has a tendency to profile specialization. Analysis of differences and application of leading experience of professional training of future coaches in Norway and Sweden will have positive impact on the improvement of national system of higher sports education and will promote improvement of efficiency of future specialists' education in the sphere of physical culture and sport/
\end{abstract}

Keywords: professional training, coach, physical culture, sport, higher educational establishment, Norway, Sweden.

\section{АНОТАЦІЯ}

У статті розглянуто досвід професійної підготовки майбутніх фахівиів фізичної культури $i$ спорту у закладах вищяої освіти Норвегї та Швеції. Проаналізовано роботи вітчизняних науковців, щчо стосуються практики реалізації професійної підготовки фахівців фізичного культури і спорту у зарубіжних краӥнах. 
sciendo Порівняльна професійна педагогіка 9(2)/2019 Comparative Professional Pedagogy 9(2)/2019

Доведено актуальність дослідження професійної підготовки майбутніх тренерів 3 виду спорту у закладах вищої освіти Скандинавії, зважаючи на те, щзо крайни півострова активно пропагують досягнення у спорті, переваги фізичної культури, здорового способу життя, оздоровчої рухової активності та якісної підготовки кадрів відповідного профілю. Метою статті є визначення основних засад системи професійної підготовки майбутніх фахівців фізичної культури $і$ спорту, зокрема тренерів з виду спорту, у провідних закладах вищої освіти Норвегії та Швеції. Завдання статті полягають в аналізі сучасного стану фізкультурно-спортивної освіти Норвегії та Швеції; кваліфікаційних напрямів й організаційних особливостей професійної підготовки майбутніх фахівців сфери фізичної культури $і$ спорту в закладах вищої освіти зазначених краӥн. У роботі охарактеризовано освітні програми підготовки бакалаврів і магістрів спортивного профілю в Норвегії та Швеції. Визначено особливості навчальних програм професійної підготовки тренерів з виду спорту провідних вищих навчальних закладів фізкультурно-спортивного профілю цих крайн. Наведено програми навчальних планів Норвезького університету спорту та Шведської школи спорту та наук про здоров'я. Встановлено, щьо характерним для системи вищої спортивної освіти Норвегії та Швещії є те, щуо освітня траєкторія підготовки фахівиів виражається в послідовності етапів навчання, яку здійснює студент для отримання знань, навичок, компетениій та має тенденцію до профільної спеціалізачії. Вивчення відмінностей та використання передового досвіду професійної підготовки майбутніх тренерів у Норвегї та Швеції матиме позитивний вплив на вдосконалення положень вітчизняної системи спортивної освіти та сприятиме підвищенню ефективності вищої освіти майбутніх фахівців сфери фізичної культури і спорту.

Ключові слова: професійна підготовка, тренер, фізична культура, спорт, заклади вищої освіти, Норвегія, Швеиія.

\section{INTRODUCTION}

As a specific multifunctional phenomenon and a separate sphere of human activity, physical culture and sport have gained great importance for the state, society, and individuals. Effective development and management of the sphere of physical culture and sports under conditions of modern intensive integration processes cannot be done without appropriate personnel. Present-day colleges of physical culture and sport need qualified specialists with a higher educational degree, who are able to implement the required functions according to demands of modern labor market taking into account innovation health-protection technologies. Personnel in the sphere of physical culture and sport are one of the key aspects of professional physical-culture and sports education. It is also the most important area and primary task of national strategy of physical culture development. Training of personnel and advanced training of individuals engaged in physical culture and sport are presented in the Concept of State Social Target Program of Physical Culture and Sports Development for the period till 2020 as a priority area of state policy regarding this sphere (Decree of the Cabinet of Ministers of Ukraine, 2015). Since 2007 Ukraine has been a member of UNESCO Intergovernmental Committee for physical education and sport (CIGEPS). At present, development of physical culture and sport and professional training of specialists in this sphere are one of the perspective areas of cooperation between Ukraine and UNESCO.

Modernization strategy for the system of higher physical education focuses on integration to world's educational and scientific space, improvement of its quality and 
sciendo Порівняльна професійна педагогіка 9(2)/2019 Comparative Professional Pedagogy 9(2)/2019

quick reacting to innovation changes on the market of physical-culture and sport services. Given these facts, many countries put a lot of effort into formation of the system of professional training of future specialists in physical culture and sport.

\section{THE AIM OF THE STUDY}

The aim of the research is to analyze experience in professional training of future specialists in physical culture and sports, namely sports coaches, in leading higher educational establishments of Norway and Sweden.

\section{THEORETICAL FRAMEWORK AND RESEARCH METHODS}

Analysis of references shows significant growth interest to issues of organization of the process of professional training of specialists in physical culture and sports in Ukraine. Individual aspects of organization of the process of professional training of students in higher educational establishments were the subject of research in works of the following researchers: M. Dutchak, H. Lozhkin, Yu. Michuda, V. Platonov, O. Tymoshenko, N. Volyanyuk, V. Voronova et al.

Research of the practice of realization of professional training of specialists in physical culture and sports abroad is of great interest. Foreign experience in training of specialists in this sphere was researched by the following native researchers: L. Sushchenko (professional training of future specialists in physical education and sports abroad) (Sushchenko, 2003); R. Karpyuk (professional training of future specialists in adaptive physical education abroad) (Karpyuk, 2008); A. Svatiyev (professional; training of specialists in sport and physical culture in countries of Eastern Europe and Asia-Pacific region) (Svatiyev, 2013); Ye. Pavlyuk (vocational training of future coaches-teachers in the USA, Germany, and Poland) (Pavlyuk, 2014) et al.

Peculiarities of professional training of future coaches in Scandinavian countries are not well analyzed in works by native researchers despite the fact that these countries promote physical culture and healthy lifestyle, have great achievements in sports. Thus, Sweden accounts for 51 national sports federations, of which 48 are engaged in development of a single kind of sports. 3 develop different kinds of sport. Norway accounts for over 12 thousand sport clubs for professional athletes. In late 90s, a trend called "Sports for everyone", which has gained popularity in European countries and Ukraine over the past decades, was established in Norway.

In order to achieve the aim methods of theoretical analysis and synthesis, as well as the method of educational documents analysis were used.

\section{RESULTS}

Most European Universities and institutes of physical culture have been united into European Network of Sport Science, Education, and Employment (ENSSEE). The aim of this organization is to focus on development of sport and sport science, while its priority activity is cooperation of sport higher educational establishments in creation of curricula that would meet the demands of labor market in European Union (Hrinchenko, 2013, pp. 4-5).

Norway was among first countries to start implementation of the aims of Bologna process. The country's labor market is considered to be one of the most appealing with its low level of unemployment $(4.5 \%)$ and good opportunities for employment of graduates, their professional development, and mobility.

The system of higher education of Norway includes state universities, specialized universities, institutes of arts, state colleges that realize professional higher education, and private colleges. The country has adopted a three-level system of academic degrees: bachelor's degree, master's degree, and doctoral degree. Bachelor's degree requires three 
years of study, after completion of which students get a diploma that equals to 180 credits (ECTS). At the same time, there exist four-level bachelor's degree programs that are primarily designed for creative professions. Norwegian universities require profound understanding of the field that students will be studying at graduate level. That is why it is required after completion of bachelor's degree in the same or related specialty.

Professional training of specialists in the sphere of physical culture and sport is done in a specialized university - Norwegian School for Sport (Norgesidrettshøgskole, $N I H)$ (2018), which is a state higher educational establishment of national significance. The university researches the issue physical culture and sport, provides training, and awards professional qualification ranks to specialists in this sphere. Over the past decade, the university has been a national center of sports expertise and has been engaged in elaboration of official sport standards and methods.

Professional training of future specialists in physical culture and sport in Norwegian School for Sport is distinguished with a variety of fields and content of specialized bachelor's degree programs: coaching activity and sports psychology; physical education of various groups of society; sports management, sports in society; outdoor physical education and a teacher at a department of physical education and sport subjects.

Training of coaches and sport psychologists at the first academic level (Bachelor $i$ trenerrollenogidrettspsykologi) envisages a three-year term of studies totaling 180 credits (ECTS) in NIH. Curricula for training of specialists in physical culture and sport have been developed in accordance with "The Ordinance on limit plan of a three-year training of teachers in practical and aesthetic subject areas" (2013).

First year of studies includes general subjects for all programs of bachelor's degree (30 credits (ECTS)), the rest - specific to each program that give a student multidisciplinary basic knowledge and skills. During the first year of studies students acquire basic theoretical knowledge and practical skills regarding the role of a coach, sports psychologist taking into account peculiarities of present-day market of sports services; they form skills in planning, organization, testing and assessment, psychological support of individual athletes of various qualification and age as well as teams as a whole.

On the second year of studies, students choose one of two profiles: coaching or sports psychology, which allows broadening of knowledge and formation of practical skills as well as acquisition of professional experience, namely due to a number of optional courses and participation in international exchange programs. At this stage of studies, students who choose coaching can choose a specific kind of sports that they can attach to practicum. During practicum $\left(2^{\text {nd }}-3^{\mathrm{d}}\right.$ year of studies $)$, which is organized in cooperation with Sports Association of Norway and/or association, club of the chosen kind of sports, students obtain practical skills in future professional activity.

Basic tasks of the third year of studies include direct training of students to fulfill professional duties regarding specific professional tasks and writing a bachelor's thesis (bacheloroppgave) (table 1).

Students' performance assessment is done with testing throughout academic year and includes a broad range of assessment methods: examination (verbal, written, distance), weekly tasks, compulsory reporting, student presentations, thematic research, group projects, seminars etc.

Thus, bachelor's degree allows mastering basic modern sciences and practical knowledge in coaching activity; it gives training for future specialist to complete tasks related to practices, studies, and organization of physical culture and sports for children, 
teenagers, athletes of various qualifications and levels, physically-challenged people. Students study peculiarities of practical activity of a coach and sports psychologists within the process of completing specific educational projects, having practicum, completion of scientific projects.

Table 1

The structure of bachelor's degree curriculum

(Bachelor i trenerrollenogidrettspsykologi) for "Coaching and sports psychology" educational program in Norgesidrettshøgskole, Oslo (2018)

\begin{tabular}{|c|c|c|}
\hline Subject code & Subject name & ECTS \\
\hline \multicolumn{3}{|c|}{$\mathbf{1}^{\text {st }}$ year(compulsory subjects) } \\
\hline IDR107 & Sport and society & 10 \\
\hline IDR109 & Physical exercises science & 10 \\
\hline IDR111 & Ball games 1 & 5 \\
\hline IDR112 & Ball games 2 & 5 \\
\hline IDR113 & Individual kinds of sport 1 & 5 \\
\hline IDR114 & Individual kinds of sport 2 & 5 \\
\hline Ti100 & Psychology of sport and sports activity & 10 \\
\hline THP101 & Functional anatomy & 10 \\
\hline \multicolumn{3}{|c|}{$2^{\text {nd }}$ year (compulsory subjects) } \\
\hline TCI230 & Coaching 1 & 10 \\
\hline TCI240 & Specialization / Studies 1 & 10 \\
\hline TCI241 & Specialization / Studies 2 & 10 \\
\hline TCI250 & $\begin{array}{l}\text { Sports psychology } 1-\text { Motivation and } \\
\text { education in sport and physical activity }\end{array}$ & - \\
\hline TCI255 & $\begin{array}{l}\text { Sports psychology } 2 \text { - Psychology of } \\
\text { efficiency in sport }\end{array}$ & 10 \\
\hline STA200 & Statistics methods & 5 \\
\hline VTM200 & Theory and methods of sport science & 5 \\
\hline $\mathrm{CPR}$ & Instructor's course - first aid & - \\
\hline \multicolumn{3}{|c|}{$\mathbf{3}^{\text {rd }}$ year (compulsory subjects) } \\
\hline TCI331 & Coaching 2 & 10 \\
\hline TCI342 & Specialization / Studies 3 & 10 \\
\hline TCI390 & Scientific project & 10 \\
\hline \multicolumn{3}{|c|}{$\mathbf{3}^{\text {rd }}$ year (recommended optional subjects) } \\
\hline TCI317 & Analysis system in sports & 10 \\
\hline TCI355 & Applied sports psychology & 10 \\
\hline IBI217 & Nutrition and physical activity & 10 \\
\hline FAH385 & Sports medicine & 10 \\
\hline
\end{tabular}

Apart from bachelors, the university offers master's program in sports science that includes five areas: coaching and psychology; physical activity; sports medicine; physical education and pedagogy; physical culture and society totaling 120 credits (ECTS).

Masters training program in "Coaching and psychology" provides overall sports scientific competence and is designed for 2 years of studies. The first year encompasses 
compulsory courses and thematic seminars totaling 60 credits (ECTS). The second year encompasses master thesis, 60 credits (ECTS) (table 2). Masters training program is designed to improve theoretical knowledge and methods of sports science, specialized research in respective field.

Table 2

The structure of master's degree curriculum (Coachingogidrettspsykologi) for "Coaching and sports psychology" program in Norgesidrettshogskole, Oslo (2 years of studies) (2018)

\begin{tabular}{|l|l|c|}
\hline \multicolumn{1}{|c|}{ Subject code } & \multicolumn{1}{|c|}{ Compulsory subjects } & ECTS \\
\hline \multicolumn{2}{|l|}{$\mid$} & 5 \\
\hline VIT400 & Theory of sport science & 5 \\
\hline MET400 & Scientific methods of research & 10 \\
\hline MA400 & Education and management in sports & 10 \\
\hline MA401 & Psychology f sport and physical activity & 10 \\
\hline MA403 & Scientific research of sports psychology & 5 \\
\hline MET410 & Specialized methods of research in sports (scientific project) & 60 \\
\hline MA500 & Master's thesis & 5 \\
\hline \multicolumn{2}{|l|}{ Recommended methods of research (choose one) } \\
\hline MET405 & Quality research & 5 \\
\hline STA400 & Statistics & 10 \\
\hline \multicolumn{2}{|c|}{ Recommended specialization (choose one) } \\
\hline MA402 & Applied sports activity and psychology & 10 \\
\hline MA404 & Football and science &
\end{tabular}

During first year of studies, methods of teaching change depending on courses: lecture, individual work, group tasks, presentations (abstract, critical analysis of educational and training programs), and reports on completed projects. Second year of studies focuses on master's thesis, which is an individual task for each student. Dissertation master's thesis is presented as a completed project or as a scientific article published in English.

An important feature of university's educational activity is an extensive engagement of students in research activity. A number of world's leading research centers that study issue of sports injuries, sports psychology, children's and youth sports, top sport achievements function in the university.

In general, the analysis of training of future specialists in physical culture and sports proves that the Norwegian university does significant work in coaches and sports psychologists training. A multi-level system has been implemented. Totality of subjects and special courses teaching of which provides formation of the system of knowledge of general anatomy system, physiology, sports practice, sports psychology as well as applied aspects of physical activity and sports has been defined. University's graduates can use their knowledge and skills in the following spheres of professional activity: sports coach for all age categories and professional levels (including team sports); coordinator, coach, and sport manager in sport schools, clubs; coordinator and manager of Federation of Sport of Norway and specialized associations; sports psychologist.

In Sweden, professional training of specialists in physical education and sports is done in university colleges (högskola) and universities (university). Universities and college 
sciendo Порівняльна професійна педагогіка 9(2)/2019 Comparative Professional Pedagogy 9(2)/2019

in Sweden have high degree of autonomy that is manifested in the right to individually develop and implement educational programs and curricula in accordance with general aims and standards of vocational training of future specialists, which is defined in Swedish Higher Education Act (1992) and The Higher Education Ordinance (1993).

Universities in Sweden provide training for sports coaches and teachers based on curricula of three education cycles: bachelor's degree, master's degree, doctoral degree. First cycle (bachelors program) is a program of studies for those who school graduates and usually lasts for three years. Master's program is a subsequent cycle of training in a higher educational establishment and lasts for one or two years.

Bachelor's degree envisages 180 academic credits (ECTS) in major field of training, envisages three semesters ( 90 credits (ECTS)), and includes completion of a science project (15 credits (ECTS)). Education in the second cycle (master's program) envisages improvement of knowledge and skills and includes 60 credits (ECTS) throughout one academic year, or 120 credits (ECTS) throughout two academic years.

In Norwegian universities, professional training of masters in physical culture and sports is distinguished by variability of curricula content. Curricula and education plans of the first cycle are oriented on the development of applied skills and critical knowledge base for efficient labor activity in the sphere of sport, leisure, and health protection as a place for social changes. Special attention is paid to the ability to use various theories and methods for understanding and sport application analysis in the area of continuous development of society. Moreover, educational program is oriented on support of local, regional, national, and international perspectives in the sphere of sports and sports science.

Training coaching staff in done in Sweden School for Sports and Health Sciences, Institute of Physical Culture and Sport of the Army of Sweden, and in specialized faculties of universities.

Sweden School for Spot and Health Sciences (Gymnastik-ochidrottshögskolan, GIH) is the oldest sports educational establishment, a specialized state higher educational establishment, a leading research center that research issues of physical culture, sport, health-improving systems, and general human health. GIH performs the function of sport regulation state program body that is responsible for academic training of coaches, fitness coaches, instructors for motor activity, physical education teachers. Since 2011 a postgraduate course has been established in the university, which is a positive aspect of continuous education concept in the context of a complex education strategy and expands opportunities for professional mobility of graduates in physical culture and port profile (2019).

At bachelor's degree, the university provides training of specialists in the following fields: Sport science and coaching programmer; Sport and health programmer, specializing in didactics; Sport science and health science programmer; Sport management programmer.

"Sport science and coaching programmer" (Tränarprogrammet) program envisages an overall of 180 credits (ECTS) of educational workload. The structure of curriculum is composed of 6 courses that include respective module:

1) Sports science and coaching - 30 credits (ECTS): "Introduction" - 1,5 credits (ECTS); "Anatomy and physiology I" - 7,5 credits (ECTS); "Anatomy and physiology II" 7,5 credits (ECTS); "Sports history and sports in society" - 6 credits (ECTS); "Sports didactics and applied sports science" - 7,5 credits (ECTS);

2) Sports specific methodology - 30 credits (ECTS): "Theory and methodology of training I" - 7,5 credits (ECTS); "Theory and methodology of training II" - 7,5 credits (ECTS); "Theory and methodology of training III" - 7,5 credits (ECTS); "Sports medicine" 7,5 credits (ECTS); 
3) Sports science and coaching - 30 credits (ECTS): "Specialization 1" - 7,5 credits (ECTS); "Research methods" - 7,5 credits (ECTS); "Degree work" - 15 credits (ECTS);

4) Sports science and coaching II - 30 credits (ECTS): "Applied physiology" 7,5 credits (ECTS); "Sports didactics and applied sports science 2" - 7,5 credits (ECTS); "Biomechanics and motor control" - 7,5 credits (ECTS); "Sports psychology" - 7,5 credits (ECTS);

5) Sports specific methodology II - 30 credits (ECTS): "Organisation and leadership I" 7, 5 credits (ECTS); "Sports pedagogy" - 7,5 credits (ECTS); "Sports psychology" - 7,5 credits (ECTS); "Organisation and leadership II" - 7,5 credits (ECTS);

6) Sports coaching III - 30 credits (ECTS): "Coach retention" - 7,5 credits (ECTS); "Coaching at championships" - 7,5 credits (ECTS); "Optimal performance from a nutritional perspective" - 7,5 credits (ECTS); "Peak performance from a multi-disciplinary perspective" - 7,5 credits (ECTS) (theoretical multidiscipline that includes completion of a science project).

Practical training of future specialists in coaching is based on cooperation between the university and sport federations and is realized within the process of completing educational projects and practicum.

Undergraduates can continue their studies in the second cycle of training. Masters program is designed for 120 credits (ECTS) and is composed of compulsory (30 credits (ECTS)), optional courses (60 credits (ECTS)), and master qualification paper (30 credits (ECTS)) (table 3).

Table 3

The structure of master's degree curriculum for "Master education program in sport science" program (masterprogrammet i idrottsvetenskap) in Gymnastik- ochidrottshögskolan, GIH, Stockholm (2018)

\begin{tabular}{|c|c|}
\hline & \\
\hline Course name & ECTS \\
\hline First year of stu & \\
\hline Compulsory cou & \\
\hline "Sports science" & 7,5 \\
\hline "Methodology and study design in sports science" & 7,5 \\
\hline "Analytical statistics for sports science" & 7,5 \\
\hline "In depth, project specific studies" & 7,5 \\
\hline Electives & \\
\hline "Sports physiology" & 15 \\
\hline "Biomechanics and motor control" & 15 \\
\hline Second year of st & \\
\hline Optional courses (as of 2018-1 & \\
\hline "Performance and training" & 7,5 \\
\hline "Culture and learning" & 7,5 \\
\hline "Physical activity and health" & 7,5 \\
\hline "Sports psychology, motivation" & 7,5 \\
\hline Thesis & 30 \\
\hline
\end{tabular}

An important feature of education in Swedish School for Sport is improvement of the content of training of coaches via analysis of respective educational programs. Thus, topicality of optional courses is defined by scientific topics that are researched in the university during respective year. 
sciendo Порівняльна професійна педагогіка 9(2)/2019 Comparative Professional Pedagogy 9(2)/2019

Based on the results of studies, graduates acquire theoretical knowledge and practical skills needed for realization of the aims of sport movement and development of kinds of sport at national and international levels; skills in application of leading scientific experience, analysis of athletes training; ability to associate scientific theories with professional tasks of a coach and a head of a sports association/organization.

Analysis of activity of higher educational establishments in Norway and Sweden proves that they do significant work in training of specialists in the sphere of physical culture and sport, namely, coaches. Higher sports education is characterized by combination of basic scientific and professional knowledge, which is extremely important for achieving educational results. It promotes graduate's active self-realization, his competitiveness, professional mobility.

It should be noted that training of coaches primarily focuses on meeting staff needs of top-achievements and mass sports institutions. Professional training of future coaches, sports educators, sports psychologists, is viewed as the one that is oriented on preparing students to execute certain types of professional activity in the sphere of physical culture and sport. Importance of this training is stipulated by social needs. Since present-day employers need specialists who posses not only conceptual and applied basis within professional field of knowledge, but also skills that allow to efficiently use this knowledge under conditions of continuous development and constant modification related to modern tendencies in sport and physical-education health improvement spheres.

We assume this experience to be the fact that specialists in the sphere of physical culture and sport in the aforementioned countries have real opportunity for continuous improvement of qualification and post-graduate studies, re-training and acquire new qualification.

\section{CONCLUSIONS}

Under conditions of updating new standards of higher education for physical culture and sports field, namely 017 Physical culture and sport, experience of European schools of training of specialists in physical education and sport including achievements of leading higher educational establishments of Norway and Sweden should be used. The most important among them is gaining fundamental knowledge in the theory of sports training that are combined with continuous practice or completion of practical projects on the bases of scientific centers and laboratories. A characteristic feature of the system of higher physical culture and sport education of the aforementioned countries is the fact that their educational trajectory of specialists training is expressed in succession of stages of education that a student has to complete in order to acquire knowledge, skills, competences, and has a tendency to profile specialization.

We assume that the study of differences and application of leading experience in professional training of future coaches in Norway and Sweden can be a source for analysis and rethinking of points of native system of sport education and will promote improvement of efficiency of future specialists in the sphere of physical culture and sport.

\section{REFERENCES}

1. Decree of the Cabinet of Ministers of Ukraine of December 9, 2015 № 1320-p "On approval of the Concept of State Social Target Program of Physical Culture and Sports Development for the period till 2010". (2015). Retrieved from https://www.kmu.gov.ua/ ua/npas/248719473. 
sciendo Порівняльна професійна педагогіка 9(2)/2019 Comparative Professional Pedagogy 9(2)/2019

2. Hrinchenko, I. (2013). Training of specialists in the sphere of physical culture in higher educational establishments abroad. Kharkiv: KhNU,

3. Karpiuk, R. P. (2008). Professional training of future specialists of adaptive physical education: theory and methods. Lutsk: Volyn Regional Printshop".

4. Official website of Gymnastik- ochidrottshögskolan, GIH. (2019). Retrieved from https://www.gih.se/.

5. Official website of Norgesidrettshøgskole, NIH. (2019). Retrieved from https://www.nih.no/en/studies-at-nih/.

6. Pavlyuk, Ye. (2014). Theoretical and methodological basis of formation of future coaches-teachers in the process of professional training. Postdoctoral thesis. Khmelnytskyi National University, Khmelnytskyi.

7. Sushchenko, L. P. (2003). Professional training of future specialists of physical education and sport (theoretical and methodological aspect). Zaporizhia: ZSU.

8. Swedish Higher Education Act. SFS No. 1992:1434. (1992). Retrieved from http://www.regeringen.se/content/I/e6/02/15/41/92fe8fff.p ].

9. Swedish Higher Education Ordinance. SFS No. 1993: 100. Reprint: SFS 1998:1003.(1993). Retrieved from http://www.regeringen.se/content/I/e6/02/15/41/ 92 fe8fff.pdf.

10. "The Ordinance on limit plan of a three-year training of teachers in practical and aesthetic subject areas" approved by the Ministry of Education of Norway of March 18 . (2013). Retrieved from https://lovdata.no/dokument/SF/forskrift/2013-03-18-290. 